\title{
Preliminary Assessment of Chemical Elements in Sediments and Larvae of Gomphidae (Odonata) from the Blyde River of the Olifants River System, South Africa
}

\author{
Abraham Addo-Bediako *(D) and Karabo Malakane \\ Department of Biodiversity, University of Limpopo, Private Bag X1106, Sovenga 0727, South Africa; \\ karabo.malakane@ul.ac.za \\ * Correspondence: abe.addo-bediako@ul.ac.za; Tel.: +27-15-2683145
}

Received: 21 July 2020; Accepted: 17 August 2020; Published: 4 November 2020

check for updates

\begin{abstract}
Benthic macroinvertebrates and sediments can act as good indicators of environmental quality. The aim of this study was to assess the accumulation of chemical elements in the Gomphidae (Odonata) collected in the Blyde River. Seven sites were sampled for river sediments assessment and five sites for larvae (naiads) of Gomphidae bioaccumulation analysis. The tissue samples were analysed using inductively coupled plasma optical emission spectrometry (ICP-OES). The results showed high levels of all of the tested elements except $\mathrm{Cd}$ in the sediment. The mean concentrations of $\mathrm{As}, \mathrm{Cu}$ and $\mathrm{Cr}$ exceeded the standard guideline values, whereas $\mathrm{Pb}$ and $\mathrm{Zn}$ were below the standard guideline values. In the insect body tissue, the concentrations of most elements were higher than in the sediments. The elements with the highest concentrations were $\mathrm{Mn}, \mathrm{Zn}, \mathrm{Cu}$, and $\mathrm{As}$. The bioaccumulation factor (BF) showed a tendency for bioaccumulation for almost all of the selected elements in the insect. The $\mathrm{BF}$ value was high for $\mathrm{Cu}, \mathrm{Mn}, \mathrm{Sb}$, and $\mathrm{Zn}(\mathrm{BF}>1)$. The high concentrations of elements in the insect body tissue may pose a risk to fish that consume them, and subsequently to humans when fish from the river are consumed. It is therefore important to monitor the river to reduce pollution to prevent health risks in humans, especially in communities that rely on the river for water and food.
\end{abstract}

Keywords: bioaccumulation; Gomphidae; heavy metals; naiads; metalloids; pollution; sediments

\section{Introduction}

Globally, rivers and streams are threatened by anthropogenic pollution, such as toxic elements, due to intensive land-use and inadequate environmental management practices [1-3]. Though most elements occur naturally in the biogeochemical cycle, many are released into inland waters as industrial, mining, agricultural, and domestic effluents, and may be harmful to aquatic systems [4]. River sediments serve as a habitat for various benthic macroinvertebrates and can serve as a sink for elements such as heavy metals. The burrowing activity of some benthic organisms leads to their chronic exposure to sediments contaminated with chemical elements [5].

Some elements are essential micronutrients for living organisms, while some (e.g., $\mathrm{Cd}, \mathrm{Cr}$ and $\mathrm{Pb}$ ) are toxic to living organisms, even at low concentrations. The toxicity of elements in aquatic ecosystems is complex and dependent on their bioavailability. Due to their prevalence and toxicity, heavy metal contamination in aquatic ecosystems poses a serious environmental threat [6-8]. This may lead to a decline in freshwater ecosystem functioning and biodiversity [9]. The available elements in the environment (sediment and water) can be assimilated into living tissues through direct uptake and the food chain, and if accumulated at unacceptable concentrations can affect the aquatic biota [10]. 
When the contaminants are incorporated into the food chain, it poses a toxicity risk to the organisms that consume them: fish, fish-eating birds, mammals and humans [11].

Many benthic organisms represent a link for the transfer of elements from the sediments to upper trophic levels. Macroinvertebrates play a major ecological role in conveying energy from lower trophic levels upwards. They serve as food for many predatory organisms in the water including fish, which are a vital food for many rural communities, especially low-income groups [12]. Humans who regularly consume contaminated fish are at risk to genotoxic, carcinogenic, and non-carcinogenic health impairment from long-term exposure to toxic contaminants $[13,14]$. Thus, it has become increasingly important to assess the levels of chemical elements in the body tissues of aquatic organisms as an indicator of metal and metalloid pollution in aquatic systems and to determine whether the food (e.g., fish) from impacted river systems are suitable for human consumption [15].

The Blyde River is one of the main tributaries of the Olifants River System. The river serves as a source of drinking water and food (fish) to the rural communities living in the catchment. The larvae (naiads) of dragonflies (Gomphidae, order Odonata) were selected for the study. They are good ecological indicators and reflect the quality of aquatic systems [16,17]. The larvae are important predators in aquatic ecosystems and prey on benthic and planktonic invertebrates [18] and also serve as food for many fish species. The aim of the study was to assess the concentration of chemical elements (bioaccumulation) in the larvae of Gomphidae and to predict the potential risk of transfer of toxic elements to fish species.

\section{Materials and Methods}

\subsection{Study Area}

The Blyde River rises on the western slopes of the north-south trending Drakensberg Mountains and flows northwards towards the escarpment edge where it is dammed. From the dam, the Blyde River cascades down a steep series of rapids to its lower reaches, where the river again flows northwards to join the Olifants River at the town of Hoedspruit in Limpopo Province [19]. The Blyde River sub-catchment is approximately $2000 \mathrm{~km}^{2}$ in size. Geologically, the northern part of the sub-catchment is made up of crystalline gneissic and granitic rocks of the Basement Complex, underlying the catchment [19]. The sub-catchment lies partly on the escarpment and, as a result, experiences considerably higher rainfall than the other sub-catchments in the Olifants River Basin, with mean annual precipitation sometimes exceeding $1000 \mathrm{~mm}$ [19]. During the last decade, there has been an increase in human activities in the area, especially agriculture, which are likely to cause environmental pollution in the freshwater systems.

The river is subjected to various sources of anthropogenic pollution, including domestic waste (S1 and S2), agricultural runoff (S3 and S5), and industrial waste (Site 4), while S6 and S7 are nature reserves (Table 1). The sampling sites were spread along the Blyde River until near the confluence with the Olifants River. The study sites ranged between $24^{\circ} 30^{\prime} 59.46^{\prime \prime} \mathrm{S} 30^{\circ} 47^{\prime} 56.14^{\prime \prime} \mathrm{E}$ and $24^{\circ} 15^{\prime} 30.38^{\prime \prime} \mathrm{S}$ $30^{\circ} 50^{\prime} 13.22^{\prime \prime}$ E (Figure 1).

Table 1. Location, description of activities, vegetation cover and substrate type (\%).

\begin{tabular}{|c|c|c|c|c|c|c|}
\hline Site & Activity & Vegetation Cover & Cobbles & Sand & Silt & Mud \\
\hline S1 & Domestic & $70 \%$ (mainly shrubs and trees) & 50 & 20 & 20 & 10 \\
\hline S2 & Domestic/agriculture & $60 \%$ (mainly shrubs, grass, and a few trees) & 30 & 30 & 20 & 20 \\
\hline S3 & Agriculture (mainly mangoes and citrus) & $90 \%$ (mainly trees and shrubs) & 40 & 30 & 20 & 10 \\
\hline $\mathrm{S} 4$ & $\begin{array}{l}\text { Industries (mainly local furniture } \\
\text { manufacturing, automotive services and } \\
\text { fruit processing factories) }\end{array}$ & $20 \%$ (mainly shrubs and grass) & 30 & 20 & 30 & 20 \\
\hline S5 & Agriculture (mainly mangoes and citrus) & $70 \%$ (mainly trees and shrubs) & 20 & 20 & 30 & 30 \\
\hline S6 & Nature reserve (little human activity) & $80 \%$ (mainly trees, shrubs and grass) & 20 & 20 & 30 & 30 \\
\hline S7 & Nature reserve (little human activity) & $50 \%$ (mainly shrubs and grass, and a few trees) & 30 & 30 & 20 & 20 \\
\hline
\end{tabular}




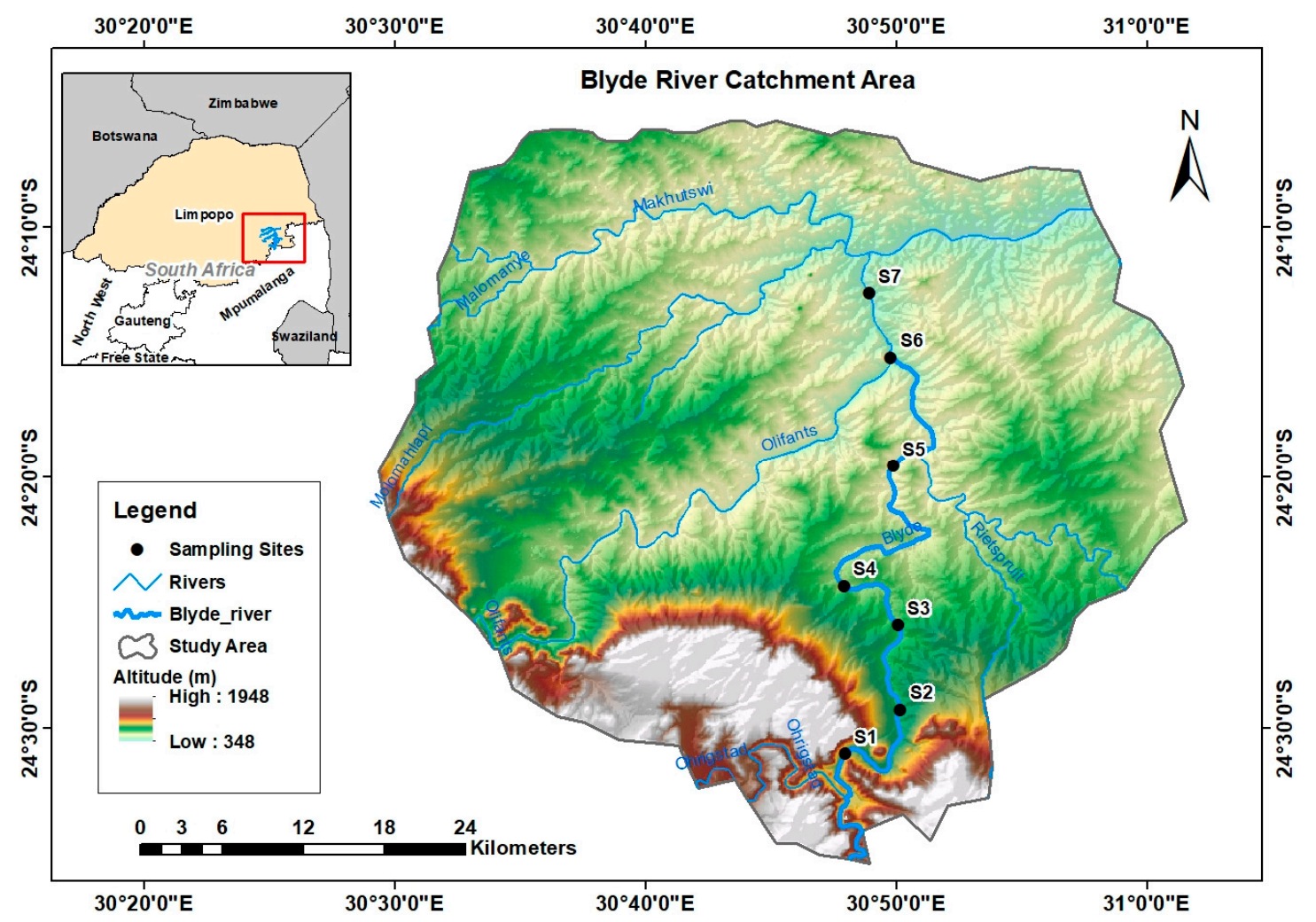

Figure 1. Map of the study area, showing the locations of the seven sampling sites of the Blyde River.

\subsection{Sampling and Analysis}

Sediment samples were collected at seven sites along the Blyde River during the months of February, April, July and October, in 2018. The samples were collected in acid pre-treated polyethylene bottles. The sediment was frozen prior to chemical analysis. Gomphidae larvae were sampled using a 30 by $30 \mathrm{~cm}$ SASS net with a $500 \mu \mathrm{m}$ mesh size [20]. The samples collected at S3 and S7 were not sufficient for chemical analysis. Sediments and macroinvertebrate samples were then analysed for elements at an accredited (ISO 17025) chemical laboratory (WATERLAB (PTY) LTD, Pretoria, South Africa). The samples were put in acid-washed polypropylene pre-weighed vials and dried at $60{ }^{\circ} \mathrm{C}$ for $24 \mathrm{~h}$, and a mixture of $\mathrm{HNO}_{3}$ and $\mathrm{HCl}$ was added. Subsequently, the samples were digested in an oven [21]. The digested samples were cooled at room temperature, filtered using filter papers, and collected in beakers. The following metals and metalloids were then analysed in batches with blanks using inductively coupled plasma-optical emission spectrometry (ICP-OES; Perkin Elmer, Optima 2100 DV, Pretoria, South Africa): Arsenic (As), Antimony (Sb), Cadmium (Cd), Chromium (Cr), Copper (Cu), Lead (Pb), Manganese (Mn), Nickel (Ni) and Zinc ( $\mathrm{Zn})$. The analytical accuracy was determined using certified standards (De Bruyn Spectroscopic Solutions 500 MUL20 - 50 STD2) and recoveries were within 10\% of certified values. The detection limits were: As—0.001 mg/kg, Cd—0.0001 mg/ $/ \mathrm{kg}, \mathrm{Cr}-0.001 \mathrm{mg} / \mathrm{kg}, \mathrm{Cu}-0.001 \mathrm{mg} / \mathrm{kg}, \mathrm{Mn}-0.0025 \mathrm{mg} / \mathrm{kg}$, $\mathrm{Ni}-0.001 \mathrm{mg} / \mathrm{kg}, \mathrm{Pb}-0.001 \mathrm{mg} / \mathrm{kg}, \mathrm{Sb}-0.001 \mathrm{mg} / \mathrm{kg}$, and $\mathrm{Zn}-0.001 \mathrm{mg} / \mathrm{kg}$.

\subsection{Statistical Analysis}

The mean and standard deviation of four samples at each site from the respective concentrations of the elements in the sediments were calculated. Analysis of variance (ANOVA) was performed using SPSS to determine whether there were significant differences among the different sites for the concentrations of the elements. Pearson's correlation matrix was used to identify the relationship between the metals. The ability of benthic macroinvertebrates to accumulate chemical elements was quantified through the bioaccumulation factors (BF) according to Klavinš et al. [22] 
The bioaccumulation factor is calculated using the following formula:

$$
\mathrm{BF}=\mathrm{C}_{\text {org }} / \mathrm{C}_{\text {sediment }}
$$

where $C_{\text {org }}$ is the element mass fraction in the organism ( $\mathrm{mg} \mathrm{kg}^{-1}$ dry weight) and $\mathrm{C}_{\text {sediment }}$ is the element concentration of the sediment ( $\mathrm{mg} \mathrm{kg}^{-1}$ dry weight).

\section{Results and Discussion}

The mean concentrations of the elements in the sediment samples at the different sites are shown in Table 2. The concentrations of As, $\mathrm{Cu}$ and $\mathrm{Sb}$ varied significantly among the different sites $(p<0.05)$. The variations in the concentrations of the elements among sites could be due to the type of effluents washed into the river from the catchment. The highest concentrations of $\mathrm{As}, \mathrm{Cu}, \mathrm{Sb}$, and $\mathrm{Zn}$ were recorded at S3. The highest concentrations of $\mathrm{Cr}, \mathrm{Mn}$ and $\mathrm{Ni}$ were recorded at $\mathrm{S} 5$, and the highest concentrations of $\mathrm{Cd}$ at $\mathrm{S} 6$.

The high concentrations of most of the chemical elements may be due to direct or indirect land surface runoff of agricultural fields at S3 and the release of urban sewage and industrial effluents at S5 $[23,24]$. Furthermore, the grain-size distribution of the sediments at different sites could have also contributed to the type and concentrations of the elements. The proportion of finer particles at S5 was higher than that of coarse grains and may have contributed to the high concentration of chemical elements. Thus, as the grain size decreases, the metal content increases [25,26]. The mean concentration of As was greater than the CCME [27] guideline value of $13 \mathrm{mg} \mathrm{kg}^{-1}, \mathrm{dw}$ at all the sites. The high As concentration at $\mathrm{S} 3$ might have been coming from pesticides and fertilizers used in agricultural fields [28,29]. The mean concentrations of $\mathrm{Cr}$ exceeded the guideline value of $37.3 \mathrm{mg} \mathrm{kg}^{-1}, \mathrm{dw}$ at all the sites. Chromium and its salts are used in pigments and paints, in fungicides, and in chrome alloy and chromium metal production [30]. In this study, the main source of $\mathrm{Cr}$ in the sediment was mainly from agricultural activities. The concentration of $\mathrm{Cu}$ exceeded the guideline value of $37.3 \mathrm{mg} \mathrm{kg}^{-1}, \mathrm{dw}$ at all the sites except $\mathrm{S7}$. The high concentration of $\mathrm{Cu}$ in the study sites could be attributed to agricultural activities (pesticides, herbicides and fungicides) and to municipal wastewater and discharges from the catchment. 
Table 2. Concentrations ( $\mathrm{mg} \mathrm{kg}^{-1}$ ) of chemical elements at different sites in the Blyde River sediment samples.

\begin{tabular}{|c|c|c|c|c|c|c|c|c|c|c|c|c|c|c|c|}
\hline Element & \multicolumn{2}{|c|}{ S1 } & \multicolumn{2}{|c|}{ S2 } & \multicolumn{2}{|c|}{ S3 } & \multicolumn{2}{|c|}{ S4 } & \multicolumn{2}{|c|}{ S5 } & \multicolumn{2}{|c|}{ S6 } & \multicolumn{2}{|c|}{ S7 } & SQG \\
\hline As & 29.04 & 19.6 & 57.2 & 59.2 & 107.57 & 49.3 & 51.03 & 40.5 & 44.88 & 46.6 & 50.79 & 46.0 & 6.23 & 3.6 & 5.9 \\
\hline $\mathrm{Cr}$ & 56.33 & 15.5 & 48.9 & 16.8 & 98.24 & 42.5 & 80.44 & 50.3 & 108.0 & 73.8 & 41.5 & 12.8 & 76.1 & 449 & 37.3 \\
\hline $\mathrm{Cu}$ & 36.74 & 20.4 & 82.0 & 90.2 & 274.34 & 148.3 & 73.99 & 50.8 & 63.46 & 52.8 & 63.62 & 62.1 & 15.23 & 8.9 & 35.7 \\
\hline $\mathrm{Mn}$ & 494.6 & 69.1 & 748.7 & 530.4 & 1175 & 490.5 & 949.8 & 635 & 1298.8 & 776 & 685.31 & 263 & 984.3 & 404 & - \\
\hline $\mathrm{Sb}$ & 1.48 & 1.1 & 8.19 & 7.71 & 24.74 & 6.7 & 6.3 & 5.6 & 7.24 & 7.0 & 7.11 & 5.4 & 0.4 & 0.69 & - \\
\hline $\mathrm{Zn}$ & 29.19 & 24.2 & 30.1 & 22.19 & 75.68 & 62.2 & 48.26 & 25.0 & 38.58 & 23.6 & 42.83 & 38.7 & 45.58 & 40.9 & 123 \\
\hline
\end{tabular}

AVE: Average; SD: standard deviation; ND—not detected. SQG: Sediment quality guideline (CCME). 
The correlation matrix showed a very strong relationship between $\mathrm{Cr}$ and $\mathrm{Ni}(0.868), \mathrm{Cu}$ and $\mathrm{Zn}$ (0.897), and $\mathrm{Pb}$ and $\mathrm{Zn}(0.766)$, at a significance level of 0.01 . There was a strong relationship between As and $\mathrm{Cr}(0.635), \mathrm{Cd}$ and $\mathrm{Cu}(0.760), \mathrm{Cr}$ and $\mathrm{Mn}(0.679), \mathrm{Ni}$ and $\mathrm{Mn}(0.750)$, and $\mathrm{Cd}$ and $\mathrm{Zn}(0.727)$ at a significance level of 0.05 (Table 3). These results indicated that these elements originated from similar pollution sources. The absence of a correlation among some of the elements suggests that they are not controlled by a single factor [31]. The high concentrations of these elements in the sediments may pose an ecological risk to the aquatic biota, especially bottom-dwelling organisms. The concentration of $\mathrm{Cd}$ was very low in the river. The relatively low levels of the elements at the downstream sites (S6 and S7) is attributed to the nature conservation practices at these two sites. This is an indication that the conservation practice is having a positive impact on the downstream of the river.

Table 3. The correlation coefficients between chemical elements of the sediments in the Blyde River.

\begin{tabular}{cccccccccc}
\hline Element & $\mathbf{S b}$ & $\mathbf{A s}$ & $\mathbf{C d}$ & $\mathbf{C r}$ & $\mathbf{C u}$ & $\mathbf{P b}$ & $\mathbf{M n}$ & $\mathbf{N i}$ & $\mathbf{Z n}$ \\
\hline $\mathrm{Sb}$ & 1 & 0.217 & 0.103 & 0.099 & -0.271 & -0.389 & 0.574 & 0.452 & -0.289 \\
$\mathrm{As}$ & & 1 & 0.111 & 0.635 & 0.259 & -0.342 & 0.597 & 0.386 & -0.161 \\
$\mathrm{Cd}$ & & & 1 & -0.452 & 0.760 & 0.368 & -0.110 & -0.552 & 0.727 \\
$\mathrm{Cr}$ & & & & 1 & -0.086 & -0.500 & 0.679 & 0.868 & -0.392 \\
$\mathrm{Cu}$ & & & & & 1 & 0.586 & -0.202 & -0.386 & 0.897 \\
$\mathrm{~Pb}$ & & & & & & 1 & -0.531 & -0.628 & 0.766 \\
$\mathrm{Mn}$ & & & & & & & 1 & 0.750 & -0.467 \\
$\mathrm{Ni}$ & & & & & & & & 1 & -0.556 \\
$\mathrm{Zn}$ & & & & & & & & & 1 \\
\hline
\end{tabular}

The tissue of Gomphidae (Odonata) was analysed for these chemical elements; As, Cd, Cr, Cu, $\mathrm{Mn}, \mathrm{Ni}, \mathrm{Pb}, \mathrm{Sb}$ and $\mathrm{Zn}$. Aquatic insects can accumulate pollutants such as heavy metals from stream sediments and from food $[32,33]$. There were significant differences in the concentrations of $\mathrm{Mn}, \mathrm{Ni}$, $\mathrm{Pb}$ and $\mathrm{Zn}$ recorded in the body tissues of the insect larvae $(p<0.05)$. The concentrations of the elements in the body tissues varied among the sites, with the highest concentrations of all the elements with the exception of Mn and Ni were at S1. The concentrations of most of the elements in the aquatic insect were about five to 10 times those of the sediments. The larvae bioaccumulated lower concentrations at the downstream site, S6 (Table 4). The highest bioaccumulation of elements was at S1, instead of S3 or S5, which had the highest concentrations of most of the elements in the sediments and could partly be due to the local bioavailability of these elements.

Table 4. Concentration of chemical elements (Mean \pm S.E) in the tissue of Gomphidae (Odonata) larvae at different sites of the Blyde River (S.E: standard deviation).

\begin{tabular}{cccccc}
\hline Element & S1 & S2 & S4 & S5 & S6 \\
\hline $\mathrm{As}$ & $32.26 \pm 0.0$ & $19.81 \pm 2.4$ & $12.32 \pm 0.0$ & $16.59 \pm 3.5$ & $7.3 \pm 3.3$ \\
$\mathrm{Cd}$ & $0.56 \pm 0.0$ & $0.28 \pm 0.03$ & $0.17 \pm 0.0$ & $0.09 \pm 0.03$ & $0.25 \pm 0.25$ \\
$\mathrm{Cr}$ & $13.81 \pm 0.0$ & $4.59 \pm 1.78$ & $2.05 \pm 0.0$ & $5.55 \pm 2.2$ & $1.82 \pm 0.53$ \\
$\mathrm{Cu}$ & $187.13 \pm 0.0$ & $101.07 \pm 28.1$ & $78.18 \pm 0.0$ & $61.1 \pm 29.2$ & $52.9 \pm 26.6$ \\
$\mathrm{Mn}$ & $3173 \pm 0.0$ & $2106 \pm 395$ & $3068 \pm 0.0$ & $3637 \pm 1038$ & $563.2 \pm 33.6$ \\
$\mathrm{Ni}$ & $11.13 \pm 0.0$ & $8.17 \pm 2.79$ & $9.99 \pm 0.0$ & $29.47 \pm 10.3$ & $6.23 \pm 5.7$ \\
$\mathrm{~Pb}$ & $1.9 \pm 0.0$ & $0.55 \pm 0.1$ & $0.33 \pm 0.0$ & $1.11 \pm 0.6$ & $0.38 \pm 0.05$ \\
$\mathrm{Sb}$ & $3.54 \pm 0.0$ & $0.97 \pm 0.05$ & $1.46 \pm 0.07$ & $2.18 \pm 0.95$ & $1.03 \pm 0.17$ \\
$\mathrm{Zn}$ & $362.2 \pm 0.0$ & $168.2 \pm 3.9$ & $183.8 \pm 0.0$ & $108.7 \pm 57.6$ & $102.3 \pm 41.2$ \\
\hline
\end{tabular}

Most of the elements detected in high concentrations in the sediments and in the insect larvae are widely used in several fertilizers as a source of micronutrients. The larvae of Odonata are known to tolerate heavy metals [34]. The concentrations of $\mathrm{Cd}, \mathrm{Cu}, \mathrm{Zn}$ and $\mathrm{Mn}$ were found in higher concentrations $(>50 \%)$ in the insect tissue than in the sediment. Meanwhile, the concentrations of As, $\mathrm{Cr}, \mathrm{Ni}, \mathrm{Pb}$ and $\mathrm{Sb}$ were higher in the sediments than in the tissue of the larvae (Figure 2). The elements 
in high concentrations in the sediments, such as $\mathrm{Mn}, \mathrm{Cu}$ and $\mathrm{Zn}$, were highly bioaccumulated in the insects. In this study, the transfer of $\mathrm{Cr}, \mathrm{Ni}$ and $\mathrm{Sb}$ into the body tissue of the insect larvae was relatively less efficient, whereas $\mathrm{Cu}, \mathrm{Mn}$ and $\mathrm{Zn}$ showed relatively high transfer efficiency. In aquatic insects, the concentrations of $\mathrm{Cd}, \mathrm{Ni}, \mathrm{Cr}, \mathrm{As}, \mathrm{Pb}, \mathrm{Cu}, \mathrm{Ti}, \mathrm{Zn}$ and $\mathrm{Mn}$ change with size, life cycle stages, and different bioaccumulation patterns [35]. For example, Caddisflies have been found to accumulate $\mathrm{Pb}$, regulate $\mathrm{Zn}$ and $\mathrm{Cu}$, while Stoneflies accumulate $\mathrm{Pb}$ and regulate $\mathrm{Zn} \mathrm{[36].}$

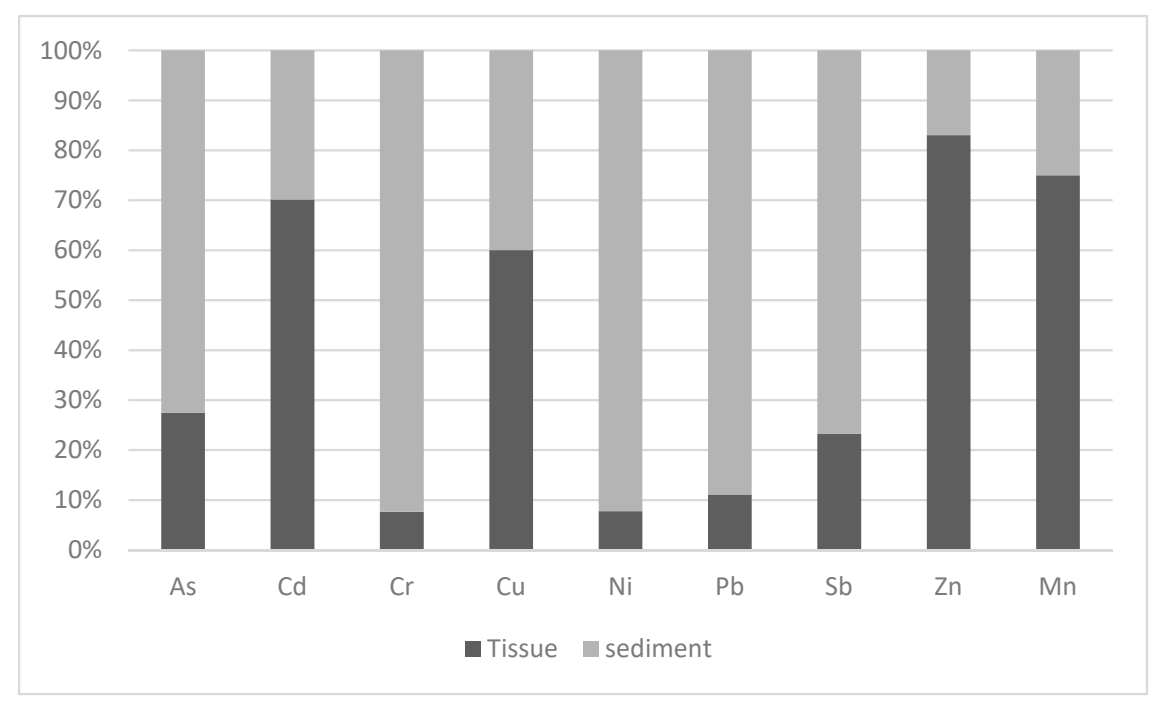

Figure 2. Composition of chemical elements in the sediments and the tissue of Gomphidae larvae.

The bioaccumulation factor (BF) of the elements in the insect larvae of Gomphidae from the Blyde River are shown in Figure 3. The BF value was $>1$ for $\mathrm{Cu}, \mathrm{Mn}, \mathrm{Sb}$ and $\mathrm{Zn}$, thus these elements may be transferred to fish, and then to humans who consume fish from the river. The BF was high at the upstream sites, S1 and S2, indicating a high bioavailability of the elements for the insect larvae, whereas the lowest BF was at S6 (downstream site), with relatively low concentrations of the elements in the sediments. The results show that the larvae of Gomphidae accumulate chemical elements from the environment and they can be used to detect metal and metalloid pollution in aquatic environments [37].

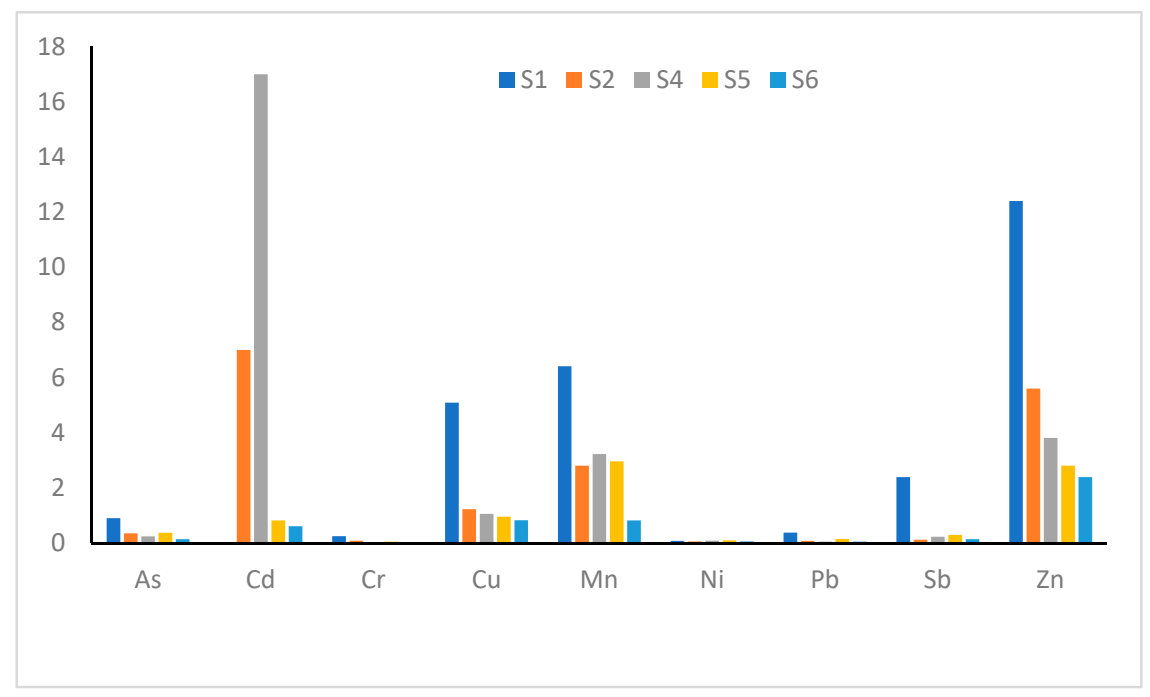

Figure 3. Bioaccumulation factor (BF) for larvae of Gomphidae samples from the Blyde River (ratio of concentrations of chemical elements in the larval tissue and in the sediment). 


\section{Conclusions}

The metal and metalloid analysis of the river sediments showed variations in their concentrations among the sites. The effects of these elements may have consequences not only on aquatic insects, but also on higher trophic levels, such as fish and humans. In the insect body tissue, the concentrations of most of the chemical elements were higher than in the sediments, meaning that the insects accumulated the elements from the sediments. The study suggests that the concentrations of many of the elements studied are too high in the sediment and the larval tissue; it is therefore necessary to monitor and control chemical pollution in the river. Further study is required to assess the level of accumulation in the different functional groups of macroinvertebrates and to determine the transfer of toxic elements through the food chain.

Author Contributions: Conceptualization, A.A.-B., K.M.; Methodology, K.M. Formal Analysis, A.A.-B.; Investigation, K.M.; Writing-Original Draft Preparation, A.A.-B.; Writing-Review and Editing, A.A.-B., K.M.; Funding Acquisition, A.A.-B. All authors have read and agreed to the published version of the manuscript.

Funding: This project was funded by a grant from the Belgian VLIR-IUC (Vlaamse Interuniversitaire Raad-University Development Cooperation) Funding Programme.

Acknowledgments: The authors thank the Belgian VLIR-IUC (Vlaamse Interuniversitaire Raad-University Development Cooperation) Funding Programme, for funding.

Conflicts of Interest: The authors declare no conflict of interest.

\section{References}

1. Ferreira, A.R.L.; Sanches Fernandes, L.F.; Cortes, R.M.V.; Pacheco, F.A.L. Assessing anthropogenic impacts on riverine ecosystems using nested partial least squares regression. Sci. Total Environ. 2017, 583, 466-477. [CrossRef]

2. Santos, R.M.B.; Sanches Fernandes, L.F.; Cortes, R.M.V.; Varandas, S.G.P.; Jesus, J.J.B.; Pacheco, F.A.L. Integrative assessment of river damming impacts on aquatic fauna in a portuguese reservoir. Sci. Total Environ. 2017, 601-602, 1108-1118. [CrossRef]

3. Addo-Bediako, A.; Matlou, K.; Makushu, E. Heavy metal concentrations in water and sediment of the Steelpoort River, Olifants River System, South Africa. Afr. J. Aquat. Sci. 2018, 43, 413-416. [CrossRef]

4. Dallas, H.F.; Day, J.A. The Effect of Water Quality Variables on Aquatic Ecosystems: A Review; Water Research Commission: Pretoria, South Africa, 2004.

5. Thomas, P.; Liber, K. An estimation of radiation doses to benthic invertebrates from sediments collected near a Canadian uranium mine. Environ. Int. 2001, 27, 341-353. [CrossRef]

6. $\mathrm{Xu}, \mathrm{J} . ;$ Chen, Y.; Zheng, L.; Liu, B.; Liu, J.; Wang, X. Assessment of heavy metal pollution in the sediment of the main tributaries of Dongting lake, China. Water 2018, 1, 1060. [CrossRef]

7. Addo-Bediako, A. Assessment of heavy metal pollution in the Blyde and Steelpoort Rivers Of The Olifants River System, South Africa. Pol. J. Environ. 2020, 29, 3023-3029. [CrossRef]

8. Venkateswarlu, V.; Venkatrayulu, C. Bioaccumulation of heavy metal lead $(\mathrm{Pb})$ in different tissues of brackish water fish Mugil cephalus (Linnaeus, 1758). J. Appl. Biol. Biotechnol. 2020, 8, 1-5.

9. Bhaskar, A.S.; Beesley, L.; Burns, M.J.; Fletcher, T.D.; Hamel, P.; Oldham, C.E.; Roy, A.H. Will it rise or will it fall? Managing the complex effects of urbanization on base flow. Freshw. Sci. 2016, 35, 293-310. [CrossRef]

10. Chen, C.Y.; Stemberger, R.S.; Klaue, B.; Blum, J.D.; Pickhardt, P.C.; Folt, C.L. Accumulation of heavy metals in food web components across a gradient of lakes. Limnol. Oceanogr. 2000, 45, 1525-1536. [CrossRef]

11. Varol, M.; Sen, B. Assessment of nutrient and heavy metal contamination in surface water and sediments of the Upper Tigris River, Turkey. Catena 2012, 92, 1-10. [CrossRef]

12. Sayer, J.; Cassman, K.G. Agricultural innovation to protect the environment. Proc. Natl. Acad. Sci. USA 2013, 110, 8345-8348. [CrossRef] [PubMed]

13. Du Preez, H.H.; Heath, R.G.M.; Sandham, L.A.; Genthe, B. Methodology for the assessment of human health risks associated with the consumption of chemical contaminated freshwater fish in South Africa. Water $S A$ 2003, 29, 69-90. [CrossRef] 
14. Jooste, A.; Marr, S.M.; Addo-Bediako, A.; Luus-Powell, W.J. Sharptooth catfish shows its metal: A case study of metal contamination at two impoundments in the Olifants River System, South Africa. Ecotoxicol. Environ. Saf. 2015, 112, 96-104. [CrossRef]

15. Addo-Bediako, A.; Marr, S.; Jooste, A.; Luus-Powell, W.J. Are metals in the muscle tissue of Mozambique tilapia a threat to human health? A case study of two impoundments in the Olifants River, Limpopo, South Africa. Ann. Limnol. Int. J. Lim. 2014, 50, 201-210. [CrossRef]

16. Haro, R.J. All along the watchtower: Larval dragonflies are promising biological sentinels for monitoring methylmercury contamination. Park Sci. 2014, 31, 70-73.

17. Pryke, J.S.; Sammays, M.J.; De Saedleer, K. An ecological network is as good as a major protected area for conserving dragonflies. Biol. Conserv. 2015, 191, 537-545. [CrossRef]

18. Nasirian, H.; Irvine, K.N. Odonata larvae as a bioindicator of metal contamination in aquatic environments: Application to ecologically important wetlands in Iran. Environ. Monit. Assess. 2017, 189, 436. [CrossRef]

19. Department of Water Affairs and Forestry (DWAF). Olifants Water Management Area: Internal Strategic Perspective; DWAF: Cape Town, South Africa, 2004.

20. Dickens, C.W.; Graham, P. The South African Scoring System (SASS) version 5 rapid bio-assessment method for rivers. Afr. J. Aquat. Sci. 2002, 27, 1-10. [CrossRef]

21. Bervoets, L.; Blust, R. Metal concentrations in water, sediment and gudgeon (Gobio gobio) from a pollution gradient: Relationship with fish condition factor. Environ. Pollut. 2003, 26, 9-19. [CrossRef]

22. Klavinš, M.; Briede, A.; Parele, A.; Rodinov, V.; Klavina, I. Metal accumulation in sediments and benthic invertebrates in lakes of Latvia. Chemosphere 1998, 36, 3043-3053. [CrossRef]

23. Pandey, J.; Singh, R. Heavy metal in sediment of Ganga River: Up- and downstream urban influences. Appl. Water Sci. 2017, 7, 1669-1678. [CrossRef]

24. Kumar, A.; Jha, K.D. Assessment of heavy metal concentration in the sediments of Mahananda River in the Seemanchal zone of Northen Bihar, India. J. Emerg. Technol. 2019, 6, 876-892.

25. Dinis, P.; Armando, A.; Pratas, J. Sources of potentially toxic elements in sediments of the Mussulo Lagoon (Angola) and implications for human health. Int. J. Environ. Res. Public Health. 2020, 17, 2466. [CrossRef]

26. Yu, T.; Zhanga, Y.; Zhanga, Y. Distribution and bioavailability of heavy metals in different particle-size fractions of sediments in Taihu Lake, China. Chem. Spec. Bioavailab. 2012, 24, 205-215. [CrossRef]

27. CCME (Canadian Council of Ministers of the Environment). Canadian Water Quality Guidelines for the Protection of Aquatic Life. In Canadian Council of Ministers of the Environment; CCME: Winnipeg, MB, Canada, 2012.

28. Wei, X.; Gao, B.; Wang, P.; Zhou, H.D.; Lu, J. Pollution characteristics and health risk assessment of heavy metals in street dusts from different functional areas in Beijing, China. Ecotoxicol. Environ. Saf. 2015, 112, 186-192. [CrossRef]

29. Zhou, J.; Liang, J.N.; Hu, Y.M.; Zhang, W.T.; Liu, H.L.; You, L.Y.; Zhang, W.H.; Gao, M.; Zhou, J. Exposure risk of local residents to copper near the largest flash copper smelter in China. Sci. Total Environ. 2018, 630, 453-461. [CrossRef]

30. WHO (World Health Organization). Guidelines for Drinking Water Quality; World Health Organization: Geneva, Switzerland, 1996; Volume 2.

31. Bhuyan, M.S.; Bakar, M.A.; Rashed-Un-Nabi, M.; Senapathi, V.; Chung, S.Y.; Islam, M.D. Monitoring and assessment of heavy metal contamination in surface water and sediment of the Old Brahmaputra River, Bangladesh. Appl. Water Sci. 2019, 9, 125. [CrossRef]

32. Prommi, T.O.; Payakka, A. Monitoring cadmium concentrations in sediments and aquatic insects (Hydropsychidae: Trichoptera) in a stream near a zinc mining area. Pol. J. Environ. Stud. 2018, 27, 2237-2243. [CrossRef]

33. Corbi, J.J.; Froehlich, C.G.; Trivinho-Strixino, S.; Dos Santos, A. Bioaccumulation of metals in aquatic insects of streams located in areas with sugar cane cultivation. Química Nova 2010, 3, 644-648. [CrossRef]

34. Tollett, V.D.; Benvenutti, E.L.; Deer, L.A.; Rice, T.M. Differential toxicity to Cd, Pb, and Cu in dragonfly larvae (Insecta: Odonata). Arch. Environ. Contam. Toxicol. 2009, 56, 77-84. [CrossRef]

35. Cid, N.; Ibánez, C.; Palanques, A.; Prat, N. Patterns of metal bioaccumulation in two filter-feeding macroinvertebrates: Exposure distribution, inter-species differences and variability across developmental stages. Sci. Total Environ. 2010, 408, 2795-2806. [CrossRef] 
36. Goodyear, K.L.; McNeillb, S. Bioaccumulation of heavy metals by aquatic macro-invertebrates of different feeding guilds: A review. Sci. Total Environ. 1999, 229, 1-19. [CrossRef]

37. Souto, R.M.G.; Juliano, J.; Corbi, J.J.; Jacobucci, J.B. Aquatic insects as bioindicators of heavy metals in sediments in Cerrado streams. Limnetica 2019, 38, 575-586. [CrossRef]

Publisher's Note: MDPI stays neutral with regard to jurisdictional claims in published maps and institutional affiliations.

(C) 2020 by the authors. Licensee MDPI, Basel, Switzerland. This article is an open access article distributed under the terms and conditions of the Creative Commons Attribution (CC BY) license (http://creativecommons.org/licenses/by/4.0/). 